\title{
Patient-reported outcome measures (PROMs) using the MASK-air@ app in severe asthma
}

Bernardo Sousa-Pinto ${ }^{1}$, João Fonseca ${ }^{1}$, Bilun Gemicioglu ${ }^{2}$, Frederico Regateiro ${ }^{3}$, Nicola Scichilone $^{4}$, Maria-Teresa Ventura ${ }^{5}$, and Jean Bousquet ${ }^{6}$

${ }^{1}$ MEDCIDS - Department of Community Medicine Information and Health Decision Sciences Faculty of Medicine University of Porto

${ }^{2}$ Department of Pulmonary Diseases Istanbul University-Cerrahpasa Cerrahpasa Faculty of Medicine Istanbul Turkey

${ }^{3}$ Allergy and Clinical Immunology Unit Centro Hospitalar e Universitário de Coimbra Coimbra Institute of Immunology Faculty of Medicine University of Coimbra Coimbra ${ }^{4}$ DIBIMIS University of Palermo

${ }^{5}$ Interdisciplinary Department of Medicine University of Bari Medical School Unit of Geriatric Immunoallergology Bari

${ }^{6}$ University Hospital of Montpellier Montpellier France

January 12, 2022

\section{Hosted file}

PROMs severe asthma-Final 110122.docx available at https://authorea.com/users/455225/ articles/552586-patient-reported-outcome-measures-proms-using-the-mask-air-app-insevere-asthma

\section{Hosted file}

Figure 1_PROMs.docx available at https://authorea.com/users/455225/articles/552586-patientreported-outcome-measures-proms-using-the-mask-air-app-in-severe-asthma

\section{Hosted file}

Online Figure 1.docx available at https://authorea.com/users/455225/articles/552586-patientreported-outcome-measures-proms-using-the-mask-air-app-in-severe-asthma

\section{Hosted file}

Supplementary Table 1.docx available at https://authorea.com/users/455225/articles/552586patient-reported-outcome-measures-proms-using-the-mask-air-app-in-severe-asthma

\section{Hosted file}

Table 1. Correlation coefficients between different PROs in severe asthma.docx available at https://authorea.com/users/455225/articles/552586-patient-reported-outcome-measuresproms-using-the-mask-air-app-in-severe-asthma

\section{Hosted file}


Supplementary Table 2.docx available at https://authorea.com/users/455225/articles/552586patient-reported-outcome-measures-proms-using-the-mask-air-app-in-severe-asthma 